\title{
ПОДХОДЫ К РАЗРАБОТКЕ КОНЦЕПЦИИ ФИНАНСОВО-ЭКОНОМИЧЕСКОЙ БЕЗОПАСНОСТИ ПРЕДПРИЯТИЙ В УСЛОВИЯХ РЕФОРМИРОВАНИЯ ЖЕЛЕЗНОДОРОЖНОГО СЕКТОРА
}

\begin{abstract}
В статье показано состояние железнодорожного транспорта Украины и задачи его реформирования на примере ПАО «Украинская зализныця» (ПАО «УЗ»). Целью статьи является теоретические подходы и практические рекомендации по разработке концепци финансово-экономической безопасности, что способствует реформированию железнодорожного транспорта Украины.

Обосновывается, что усиливающаяся конкуренция, разнообразие экономических и предпринимательских внутренних и внешних рисков, неопределенность условий деятельности являются характерными для современной экономики Украины. Из общей системы экономической безопасности страны выделено проблему финансовоэкономической безопасности каждого предприятия. В проведенном исследовании детальному рассмотрению были подвергнуты условия и варианты приватизации, а также акционирования объектов железнодорожного транспорта.

Аргументируется, что реформирование системы железнодорожного транспорта Украины сегодня является объективной необходимостью. Это первый шаг в процессе адаптации железнодорожного транспорта Украины к стандартам Европейского Союза. Кроме этого, создаются прозрачные механизмы для предоставления возможности частным компаниям выйти на рынок железнодорожных перевозок. Автором представлена модель угроз экономической безопасности железнодорожного транспорта Украины.

Предложен авторский подход к разработке концепции финансово-экономической безопасности предприятия. Он представлен в виде системы стратегического управления финансово-экономической безопасностью предприятия. Учет существующих и потенциальных угроз и рисков определяет оперативные и прогностические цели функционирования системы экономической безопасности. Это позволяет формировать соответствующие механизмы и инструменты ее достижения.

Утверждается, что в результате реформирования железнодорожного транспорта Украины может измениться конфигурация внутрирегиональных связей и, как следствие, повысится политический, экономический и культурный потенциал целого ряда регионов.

Ключевые слова: финансовая и экономическая безопасность, ПАО «Украинская зализныця» железнодорожный транспорт, реформа Укрзализныци, концепция, приватизация, угрозы экономической безопасности, неопределенность.
\end{abstract}

${ }^{1}$ Dr Ivan Rekun, PhD, Katedra Finansów i Bezpieczeństwa Ekonomicznego, Państwowy Uniwersytet Transportu Kolejowego w Dniepropietrowsku; e-mail: rekun_i@mail.ru 


\section{1. ВВЕДЕНИЕ}

Развитие и становление рыночных отношений приводит к необходимости пересмотра процесса реформирования госструктур, являющихся естественными монополиями, одной из которых остается государственное предприятие “Укрзализныця” (ПАО УЗ). Железнодорожный транспорт обеспечивает устойчивое функционирование отраслей материального производства, повышение эффективности использования ресурсов, сокращение за счет транспортной составляющей удельных затрат в стоимости продукции, решение социальных задач. Эти составляющие определяют стратегическое значение железнодорожной сферы в защите национальных интересов и нейтрализации угроз финансово-экономической безопасности страны в целом, поскольку транспортная составляющая занимает важное место в системе национальной безопасности.

Усиливающаяся конкуренция, разнообразие экономических и предпринимательских внутренних и внешних рисков, неопределенность условий деятельности, характерных для современной экономики Украины, интеграция транспортных систем в европейское экономическое пространство объективно выделяют из отношений общей экономической безопасности страны проблему финансово-экономической безопасности каждого предприятия как одного из необходимых условий ее осуществления.

В связи с этим степень развития механизма финансово-экономической безопасности такой хозяйственной структуры как ПАО УЗ должна соответствовать задачам, которые возникают при ее вхождению в систему рыночных отношений. Начавшаяся поэтапная реформа железнодорожного транспорта (ЖДТ) определяет актуальность проблемы финансово-экономической безопасности каждого предприятия, входящего в его хозяйственную орбиту. К сожалению, основные направления реформирования госпредприятий Украины предлагаются, в основном, в виде изменения форм управления при стопроцентной собственности государства. Монополия такой транспортной системы изменила только форму влияния государства, но не сущность. Предприятия, входящие в ПАО, не могут конкурировать друг с другом, поскольку имеют общего собственника. А это значит, что будет отсутствовать мотивация к повышению эффективности деятельности структурных подразделений (предприятий). Проведенная рестуктуризация "Укрзализныци" не отвечает ни требованиям ЕС (допуск частных компаний), ни запросам субъектов системы железнодорожного транспорта (хозяйственная самостоятельность).

Перечисленные задачи и проблемы реформирования ЖДТ обусловили актуальность и необходимость формирования новых подходов к методологии и организации экономической безопасности. Экономическая безопасность предприятий, должна стать одним из столпов реформирования ЖДТ. Новое переосмысление роли и места экономической безопасности предприятий ЖДТ предполагает необходимость исследование и разработку мер против существующих угроз и учета рисков неожиданных потрясений, последствий экономической волатильности и интеграции транспортных систем.

\section{2. СОВРЕМЕННЫЕ ИССЛЕДОВАНИЯ}

Сегодня транспортный сектор экономики Украины в целом удовлетворяет лишь базовые потребности экономики и населения в перевозках. Уровень безопасности, 
показатели качества и эффективности перевозок пассажиров и грузов, энергетической эффективности, техногенной нагрузки на окружающую среду не отвечают современным требованиям ${ }^{2}$. Украинские ученые принимают определенное участие в решении отдельных проблем процесса реформирования ЖДТ. Например, Ю.С. Бараш рассматривает реформирование ЖДТ Украины, его акционирование и реструктуризацию отдельных хозяйственных структур как условие повышения конкурентоспособности. Н.В.Гненный разработывает принципы перехода на вертикальную форму управления отраслевыми хозяйствами железных дорог с определением специальной стоимости особенно привлекательных объектов железнодорожного транспорта, Л.С. Головкова исследует организационно-техническую подготовку развития совокупного экономического потенциала корпораций ${ }^{3}$. Концептуальные подходы к определению экономической безопасности в системе экономической науки сформулированы в работах О.С.Власюк. Аналитическое обоснование проблем реформирования железнодорожного транспорта Украины детально представлено в работах В.А. Сычова ${ }^{4}$. Весомый вклад в теорию и практику, а также раскрытие содержания и структуры экономической безопасности предприятий внесли такие ученые как В.Л. Дикань, І.В. Воловельськая, О.В. Маковоз, Компаниец, І.Л. Назаренко

\section{3. ТЕОРЕТИЧЕСКОЕ ОБОСНОВАНИЕ}

Новые подходы к разработке концепции системы финансово-экономической безопасности на предприятиях железнодорожного транспорта Украины должны дать возможность определить сущность, характер и структуру финансовоэкономической безопасности, а также условия и критерии ее описания. Критерии должны быть определены и идентифицированы. Описание содержания процессов, определение структурных и организационных функций, дает возможность прогнозирования деятельности предприятия.

Необходимость реформирования ЖДТ ни у кого не вызывет сомнений. Реформа железных дорог - это значительные изменения в государственной политике, инвестиционной стратегии и структуре управления, направленные на повышение эффективности сектора. Вместе с тем, категорически отрицается приватизация ПАО УЗ, что и поддерживается в действующем Законе Украины «О реформировании

${ }^{2}$ Транспортна стратегія України на період до 2020 року [Електронний ресурс], режим доступу: http://www.mintrans.gov.ua/uk/discussion/15621.html.

${ }^{3}$ Л.С. Головкова, Сукупний економічний потенціал корпорації: формування та розвиток: монографія., Запоріжжя: КПУ, 2009.

${ }^{4}$ В.О. Сичов, Вектори реформування залізничної галузі Украӥни, Локомотив-информ, 2013, № 5.

5 В.Л. Дикань, І.В Дикань, В.Л. Воловельська та ін., Економічна безпека підприємства, навчальний посібник, Х.: УкрДАЗТ, 2011; Дикань В.Л., Дикань І.В., Компанієць В.В. та ін., Техніко-економічний аналіз діяльності підприємств залізничного транспорту, підручник, Х.: УкрДАЗТ, 2013; Дикань В.Л., Украӥнська модель економічної системи як нова конщепиія розвитку начіональної економіки, Вісник економіки транспорту і промисловості, Збір наук. праць , Х.: УкрДАЗТ, 2013, № 44, с. 11 - 17; Дикань В.Л., Розвиток промислового потениіалу українських підприємств, Вісник економіки транспорту і промисловості, Збір. наук. праць, Х.: УкрДАЗТ, 2014, № 46, с. 136 - 142. 
железнодорожного транспорта», который отвергает возможность приватизации компании. В то же время Закон предоставляет право в будущем создавать публичные акционерные общества и выделять из своего состава определенные активы, которые не подпадают под ограничения. Это, в первую очередь, предприятия непрофильных видов деятельности, они могут быть акционированы и проданы.

Но главным является то, что после реформы эта компания будет иметь совсем другую структуру. Она будет включать развитую инфраструктуру, систему сигнализации, связи, вокзалы, здания, расположенные по путям, инженерными сооружениями и т.д. Эта часть будет обладать необходимыми объектами, содержание которых требует значительных капиталовложений. Сегодня эта государственная часть ПАО УЗ пока планируется к приватизации. Именно это отражено в действующем законе. А вот все остальные активы, прежде всего подвижной состав (сначала вагоны, а затем и локомотивный парк), в большей степени уже сейчас передаются или планируются к передаче частным компаниям с целью создания конкурентной среды. Тем самым забота о развитии и модернизации исключительно затратной и практически неприбыльной части компании инфраструктуры - остается за государством, а наиболее прибыльные активы будут контролироваться частным бизнесом. Аналитики называют такое положение вещей классической схемой, предусматривающей “национализацию долгов с одновременной приватизацией прибылей"6. Во внимание не было принято, что основной деятельностью транспортного комплекса является перевозка, а главное назначение транспорта - удовлетворять потребности экономики и населения в перевозках.

В свою очередь, инфраструктура транспорта - это вспомогательные подразделения, технические средства, строения, сооружения и т.п., которые способствуют основной деятельности (осуществление перевозок - обеспечение транспортного процесса). Реформа железнодорожного транспортного комплекса оказалась очередным волюнтаристским решением, которое принято без учета законов рынка, действующих в странах в ЕС. Они четко предполагают создание конкурентной среды и самостоятельных хозяйственных субъектов. Вопрос о соотношении между системой частной собственности, рынка и государственным присутствием на нем, в теории экономики является достаточно сложным. А.А. Ткач указывает, что использование механизма цен связано с расходами, в частности, по защите и спецификации прав собственности. В результате возникают вертикально интегрированные компании, в рамках которых также вполне возможно осуществление прав частной собственности. Однако, вследствие того, что в представлении экономистов система рынков прочно срослась с системой частной собственности, появилась идея рассматривать внутрифирменные трансакции в терминах внутрифирменных рынков ресурсов (в частности, рынка труда и капитала). Права собственности и рынок предполагает существование и реализацию правомочий, которые обычно ставят на вершину иерархии - право отчуждения, или

${ }^{6}$ В.О. Сичов, Вектори реформування залізничної галузі Украӥни. Локомотив-информ, 2013, № 5 . 
право на капитальную стоимость ${ }^{7}$. Обсуждение этой проблемы продолжается в теоретических и практических исследованиях теоретиков и практиков Украины, в которых все большую актуальность приобретает экономическая безопасность. Поэтому в последние годы в обществе шли дискуссии, в которых в адрес Государственного предприятия ПАО УЗ высказывается много замечаний и предложений.

\section{4. ОБСУЖДЕНИЕ И КРИТИЧЕСКИЕ ЗАМЕЧАНИЯ}

Критические замечания по поводу деятельности ПАО УЗ состоят в том, прежде всего, что это чуть ли не единственная железнодорожная сфера, которая не подлежала реформированию в соседних странах. С советских времен она сохранилась в неизменном виде и в функциональном плане, и по своей структуре. Главной причиной такой ситуации является недостаточный уровень финансирования, что приводит к дефициту капиталовложений в обновление основных фондов железной дороги и закупку нового подвижного состава, как вагонов, так и локомотивов. Следующей объективной причиной нехватки средств эксперты называют убыточность пассажирских и пригородных перевозок, недостаточное возмещение государством средств, недополученных от перевозки льготных категорий пассажиров, сохранение практики перекрестного субсидирования пассажирских перевозок за счет грузовых. Кроме этого, ПАО УЗ, как никогда, нуждается во внешних инвестициях. Главным препятствием для решения всех этих проблем называется соединение хозяйственной и административной функций, что приводит к «непрозрачности» деятельности ПАО У3, что также препятствует в доступе к инвестициям и кредитам. В противовес приводят примеры европейских стран, в которых благодаря успешному реформированию созданы условия для повышения конкурентности рынка перевозок и рентабельности железнодорожного транспорта. Кроме этого можно добавить, что причиной неэффективности работы является то, что железные дороги Украины обременены разного рода политическими, социальными и военностратегическими обязательствами, выполнение которых компенсируется государством не всегда своевременно и в полной мере. Реформирование железнодорожного транспорта Украины, где экономика работает в условиях неопределенности и нестабильности, является процессом необходимым, поскольку государство не в состоянии больше финансировать эту отрасль в полном объеме. Какие же пути реформирования возможны?

\section{5. ПРАКТИЧЕСКИЕ РЕЗУЛЬТАТЫ}

Финансово-экономическая безопасность предприятия базируется на результатах хозяйственной деятельности, характеризующейся достижением наибольшего экономического эффекта с применением ресурсов определенной стоимости. Для положительного результата предприятие должно обладать соответствующими технико-экономическими характеристиками. В ПАО УЗ они находятся на низком уровне, что неминуемо сказывается на безопасности деятельности компании.

${ }^{7}$ А.А. Ткач, Інституціональна економіка. Нова інституціональна економічна теорія, К.: Центр учбової літератури, 2007, 133 с. 
Состояние пассажирского подвижного состава требует немедленного восстановления. Из 6677 пассажирских вагонов, только 2985 (43\%) работают в пределах нормативного срока эксплуатации, 3644 (53\%) - с продленным сроком эксплуатации и 258 (4\%) находятся за пределами нормативного срока эксплуатации ${ }^{8}$. Практически, из 120000 грузовых вагонов ПАО УЗ более 85\% исчерпали свой ресурс, 30071 вагон по всем эксплуатационным правилам давно должны быть списаны9. Износ подвижного состава достиг критической отметки около 90\%. Сегодня, для электровозов этот показатель составляет 90\%, для грузовых магистральных тепловозов - 99\%, для вагонов инвентарного парка - 86\%, из них полувагонов - 88\%. И это при том, что обновление подвижного состава и инфраструктуры проводится очень медленно.

Без сомнений, важнейшим аспектом оценки производственной деятельности является обеспечение финансово-экономической безопасности. Это предполагает обеспечение соответствующих условий для состояния экономики, при котором достигается необходимый уровень социального, политического, финансового, оборонного развития страны, неуязвимость и независимость ее экономических интересов по отношению к возможным внешним и внутренним угрозам и воздействиям.

В составе ПАО УЗ содержится несколько дочерних предприятий. Так например, в 2011 году в рамках реформирования системы грузовых железнодорожных перевозок ПАО УЗ было создано госпредприятие «Украинский транспортнологистический центр» (УТЛЦ) с целью объединения всех украинских владельцев грузовых полувагонов под единым управлением. На сегодняшний день «УТЛЦ» работает с парком вагонов государственных вагонных компаний, в частности, 46,7 тыс. полувагонов, в том числе в рабочем состоянии - 34 тыс. Из них 2 тыс. вагонов находятся за пределами Украины. Несмотря на эту структуру, система логистического управления на железных дорогах Украина не является совершенной и нуждается в доработке. Например, широкое внедрение современных информационных технологий в перевозочный процесс, совершенствование взаимодействия железнодорожного и других, в первую очередь морского, речного и автомобильного транспорта. Из-за недостатков организации транспортного звена «грузоотправитель - экспедитор - порт - трейдер» все убытки приходятся на железную дорогу.

На европейских железных дорогах внедрено высокоскоростное движение пассажирских поездов со скоростью 200 - 250 и более километров в час. На железнодорожном транспорте Украины начали также внедрять движение пассажирских поездов со скоростью до 160 километров в час. Однако железная дорога не была готова к внедрению такого новшества. Для этого необходимо было решить достаточно сложную проблему распределения сети на линии с преимущественно грузовым и преимущественно пассажирским движениями и повысить частоту движения пассажирских поездов. Поэтому началом качественной

${ }^{8}$ А.А. Ткач, Інституціональна економіка. Нова інституціональна економічна теорія, К.: Центр учбової літератури, 2007.

${ }^{9} 3 a$ вагон - хоть в огонь [Электронный ресурс], Режим доступа: http://zadonbass.org/news/all/message_61499. 
и высокотехнологичной модернизации инфраструктуры железнодорожного транспорта Украины стало создание в 2012 году еще одной дочерней компании: Украинской железнодорожного скоростной компании (УЖСК). Это первая в Украине компания по перевозке пассажиров дневными скоростными поездами ИНТЕРСИТИ+. Кроме этого УЖСК занимается организацией, эксплуатацией и техническим обслуживанием скоростного подвижного состава отечественных и зарубежных производителей. Это государственное предприятие, которое подчинено Государственной администрации железнодорожного транспорта Украины (ПАО У3). На сегодняшний день УЖСК - единственный государственный оператор пассажирских железнодорожных перевозок, в эксплуатации которого находится новейший подвижной состав: 10 электропоездов производства компании «Hyundai Rotem» (Республика Корея); 1 поезд локомотивной тяги производства ПАО «Крюковский вагоностроительный завод» (ОАО «КВСЗ»); 2 двухсистемные электропоезда Экр-1 производства ОАО «КВСЗ».

На сегодняшний день ГП «Украинская железнодорожная скоростная компания» добилась некоторых успехов в своей деятельности. Так, например, в июне 2015 года УЖСК перевезла более 270,6 тыс. пассажиров, что стало рекордом в сфере отечественных скоростных перевозок. Как отмечают в пресс-службе предприятия, существенный рост спроса на качественный скоростной сервис наблюдался в декабре 2014 года и марте 2015 года - тогда скоростными поездам воспользовались 224,6 тыс. пассажиров и 233,7 тыс. пассажиров соответственно. Но в целом отмечается низкий спрос на скоростные перевозки. Причины называют такие:

- несовершенство конструкции корейских поездов «Hyundai Rotem», которые имеют много недоработок, что привело к многочисленным остановкам их в пути и нежеланию пассажиров путешествовать этими поездами;

- дневные поезда не решают проблемы поездок в командировку, поскольку прибывают в Киев и областные города после 12 часов, что делает невозможным решение необходимых вопросов, которые касаются работы. Поэтому все пассажиры, едущие в командировку, должны оставаться в этих городах еще на одни сутки и одновременно решать проблему поиска отеля;

- низкой скоростью движения, которая на отдельных направлениях движения не превышает 135 км / ч;

- конкуренцию дневным скоростным поездам составляют ночные фирменные поезда, в которых стоимость поездки и усталость ниже ${ }^{10}$.

В 2009 году постановлением Кабинета министров Украины от 16 декабря 2009 года №1390 была утверждена Государственная целевая программа реформирования железнодорожного транспорта на 2010-2019 годы. В результате ее выполнения ссздано публичное акционерное общество "Украинская зализныця" (ПАО УЗ) со стопроцентной собственностью государства. Считается, что одно из важных последствий корпоратизации - сокращение расходов на управление. Должности чиновников, которые дублируют друг друга в шести отдельных железных дорогах, сокращены. Сейчас ПАО УЗ - это шесть отдельных железных дорог, которые обслуживают разные области Украины, а также около 50 обособленных

${ }^{10}$ А.В. Момот, Методичні підходи до визначення ефективності курсування швидкісних та високошвидкісних поїздів, Наука та прогрес транспорту, Вісник ДНУЗТ ім. ак. В. Лазаряна, 2013, № 6 . 
предприятий, которые реформируются. Их объединяют в компанию с единым менеджментом, и за счет слияния все операции взяты под единый контроль. Железные дороги, ремонтные мастерские, вагонные компании, скоростная компания, информационно-вычислительный центр, проектный институт и другие «княжества» должны превратиться в 30 филиалов ПАО УЗ. Один из плюсов реформы - единый контроль над госзакупками и расходами, которые будут осуществляться на основе публичных аукционов. Сейчас решения, куда направлять деньги ПАО УЗ, принимаются в шести разных точках, а на более низком уровне - в десятках мест. «Удельные княжества» - это благоприятная почва для коррупции, тогда как слияние в единую корпорацию становится прямой угрозой их существованию.

Анализ опыта приватизации в соседних странах - Польше, Венгрии, Словакии показывает, что продавать убыточные государственные заводы по низким ценам означает наносить вред обществу. В таких случаях лучше всего формировать антикризисный менеджмент предприятий, который получает свободу действий, одновременно находясь под контролем государства. И только после успешного осуществления санации, когда объект становится привлекательным для потенциальных инвесторов, государство может продать свой пакет. ${ }^{11}$

Особенностью ЖДТ Украины являетя высокие издержки прокладки путей. Известно, что строительство 1 км железнодорожного электрифицированного пути стоит 15-20 млн. грн., ее модернизация - около 5 млн. грн., а содержание - примерно 250 тыс. грн. в год. Это увеличивает финансовую составляющую обновления и развития этого вида транспорта.

Еще одним важным моментом является то, что “Укрзализныця” всегда была холдингом, специфика которого заключается в разделении не по сферам деятельности, а по территориальному признаку. Дочерными компаниями выступали железные дороги и их отделения, которые, как и должно быть в холдинге, имели достаточную независимость в распоряжении долями прибыли, управлении подвижным составом, развитии сферы социальной защиты. Такие громоздкие объединения, «обремененные» социальными обязательствами, считаются непомерно тяжелым наследием социализма.

Сегодня главной социально значимой проблемой считается наличие перекрестного субсидирования, при котором убытки пассажирских перевозок, связанные с относительной дешевизной плацкарты, покрываются за счет доходности грузоперевозок. Но возможно, в перекрестном субсидировании ничего плохого и нет, поскольку оно является так называемым налогом на роскошь, обсуждение которого достаточно популярно сегодня в сфере недвижимости. Социальные обязательства переводятся в виде тарифов на грузовладельцев, то есть на крупных бизнесменов. Кроме того, мировой практике известны только два вида субсидирования - перекрестное и прямое бюджетное, поэтому отмена одного автоматически требует перехода к другому. Конечно, существует и третий вариант - отказаться от субсидирования вообще и поднять стоимость пассажирских

${ }^{11}$ А.А. Ткач, Інституціональна економіка. Нова інституиіональна економічна теорія, К.: Центр учбової літератури, 2007. 
железнодорожных тарифов до уровня авиационных (как в США), что и планируется министерством инфраструктуры. ${ }^{12}$

Важно отметить то, что смешанная форма собственности не позволяет рассчитывать только на рыночные механизмы регулирования (саморегулирования) правил взаимодействия государства и коллективного или частного владельца, она требует разработки и внедрения формальных институтов, то есть организованных правил поведения субъектов хозяйствования, включая и властные структуры, отвечающие за корпоративные права государства. Формирование названных институтов, считает А.А. Ткач, должно базироваться на “спецификации прав собственности, определяющие направления становления и регулирования рыночной инфраструктуры" ${ }^{\prime 3}$. Соотношение регулирования и дерегулирования не имеет четкой границы. Простая демонстрация методов дерегулирования, как более эффективных, не говорит о том, что регулирование является второстепенным методом организации экономической деятельности. Например, А. Уильямсон считает, что недостатки саморегулируемой политики колеблются в зависимости от вида и форм регулируемой деятельности. Все зависит от оценок конкретного транспорта, их применения, и вполне возможно, что «ожидаемые преимущества отказа от регуляции могут оказаться иллюзорными». Нечетко специфицированные права собственности на предприятиях со смешанной формой собственности являются главной причиной их банкротства. Такая ситуация хорошо известна в сфере общественной собственности, нерационального, а иногда и просто варварского использования ресурсов, находящихся в совместном использовании 14 .

\section{6. АВТОРСКАЯ РАЗРАБОТКА МОДЕЛИ УГРОЗ ФИНАНСОВО- ЭКОНОМИЧЕСКОЙ БЕЗОПАСНОСТИ ЖЕЛЕЗНОДОРОЖНОГО ТРАНСПОРТА УКРАИНЫ}

Таким образом, несмотря на то, что существуют многие проекты, предложения, по реформированию железнодорожного транспорта Украины, на сегодня эта проблема остается в стадии исследования и объективной необходимости. Это первый шаг на пути адаптации железнодорожного транспорта Украины к стандартам Европейского Союза, а также применению прозрачных финансовых и хозяйственных механизмов для предоставления возможности частным компаниям выйти на рынок железнодорожных перевозок. Главная цель реформы - повышение доходности ПАО УЗ, пропорционально росту объемов производства, увеличение инвестирования, отчислений в госбюджет, заработных плат сотрудников компании, и т. Д.

В свою очередь, Министерство инфраструктуры задачи реформирования на 2016-2017 гг. определяет таким образом: завершение создания ПАО «Украинская

${ }^{12}$ В.О. Сичов, Вектори реформування залізничної галузі України, Локомотив-информ, 2013, № 5

${ }^{13}$ А.А. Ткач, Специифікачія прав власності як базисного економічного інституту ринкової інфраструктури, Наукові праці Донецького національного технічного університету, Випуск 75, Донецьк: ДонНТУ, 2004, С.232.

${ }^{14}$ А.А. Ткач, Інституціональна економіка. Нова інституиіональна економічна теорія, К. : Центр учбової літератури, 2007, 
Зализныця» (корпоратизация и создание профильных холдингов), смена организационной структуры, принятие нового закона «О ЖДТ Украины», построение эффективной, прозрачной системы закупок, смена тарифной системы. Нужно отметить, что поставленные задачи, при всей их важности, не соответствуют многим потребностям предприятий этой сферы. В планируемых решениях отсутствует решение проблемы хозяйственной самостоятельности и ответственности предприятий, а без этого невозможно добиться эффективности и безопасного экономического развития. Поэтому так остро ставится вопрос о выявлении существующих угроз и на их основе разработки концепции системы финансово-экономической безопасности на предприятиях железнодорожного транспорта Украины. Модель угроз экономической безопасности железнодорожного транспорта Украины представлена на рис.1.

В результате проведенного анализа финансового состояния предприятий ЖДТ и предлагаемых министерством инфраструктуры изменений, предложен авторский подход к разработке концепции финансово-экономической безопасности предприятия. Он представлен в виде системы стратегического управления финансово-экономической безопасностью предприятия. Учет существующих и потенциальных угроз и рисков определяет оперативные и прогностические цели функционирования системы экономической безопасности. Это позволяет сформировать соответствующие механизмы и инструменты ее достижения.

Предложено сформировать Концепцию системы финансово-экономической безопасности предприятия, которая будет осуществлятся в 4 этапа:

I этап - анализ угроз и финансовых рисков для стратегических зон хозяйствования $(\mathrm{C} 3 \mathrm{X})$ предприятия, которые существуют в настоящее время и прогнозируются в будущем;

II этап - постановка цели формирования системы финансово-экономической безопасностью предприятия;

III этап - разработка стратегии экономической безопасности предприятия и С $3 \mathrm{X}$.

IV этап - реализация стратегии экономической безопасности предприятия.

Bсе этапы взаимосвязаны и являются составными элементами цикла стратегического управления системой финансово-экономической безопасности предприятия (см.рис.2). 
Рис.1. Модель угроз экономической безопасности предприятий железнодорожного транспортв Украины

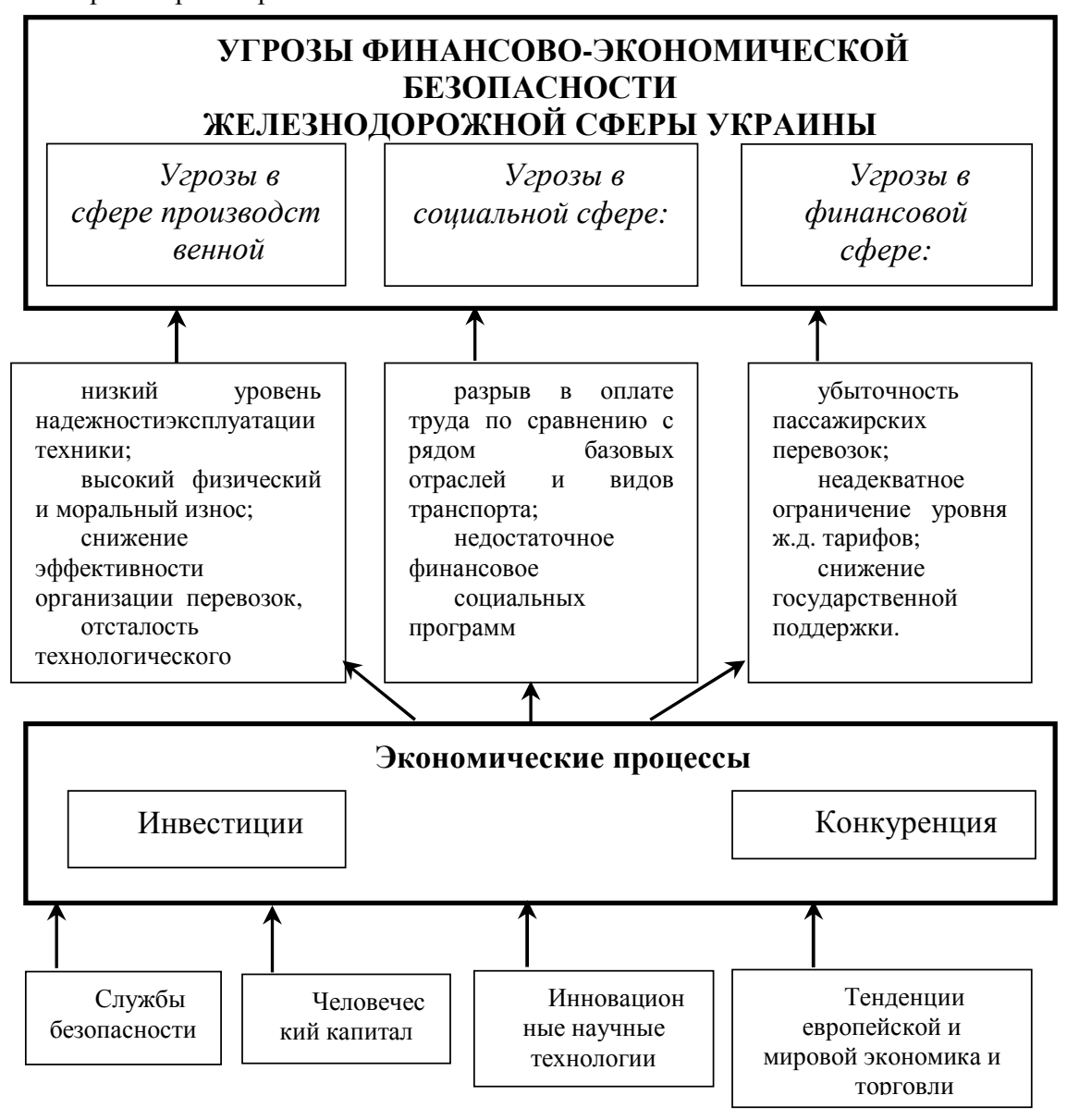

Таким образом, концепция экономической безопасности рассматривается нами в функционально-структурном аспекте, то есть как совокупность взаимосвязанных систем безопасности, отражающих функционирование отдельных «блоков» или сфер экономической системы предприятия, которые представлены на рис.1 посредством которых нейтрализуются возможные угрозы (рис.2). 
Рис.2. Управление системой финансово-экономической безопасности предприятия.

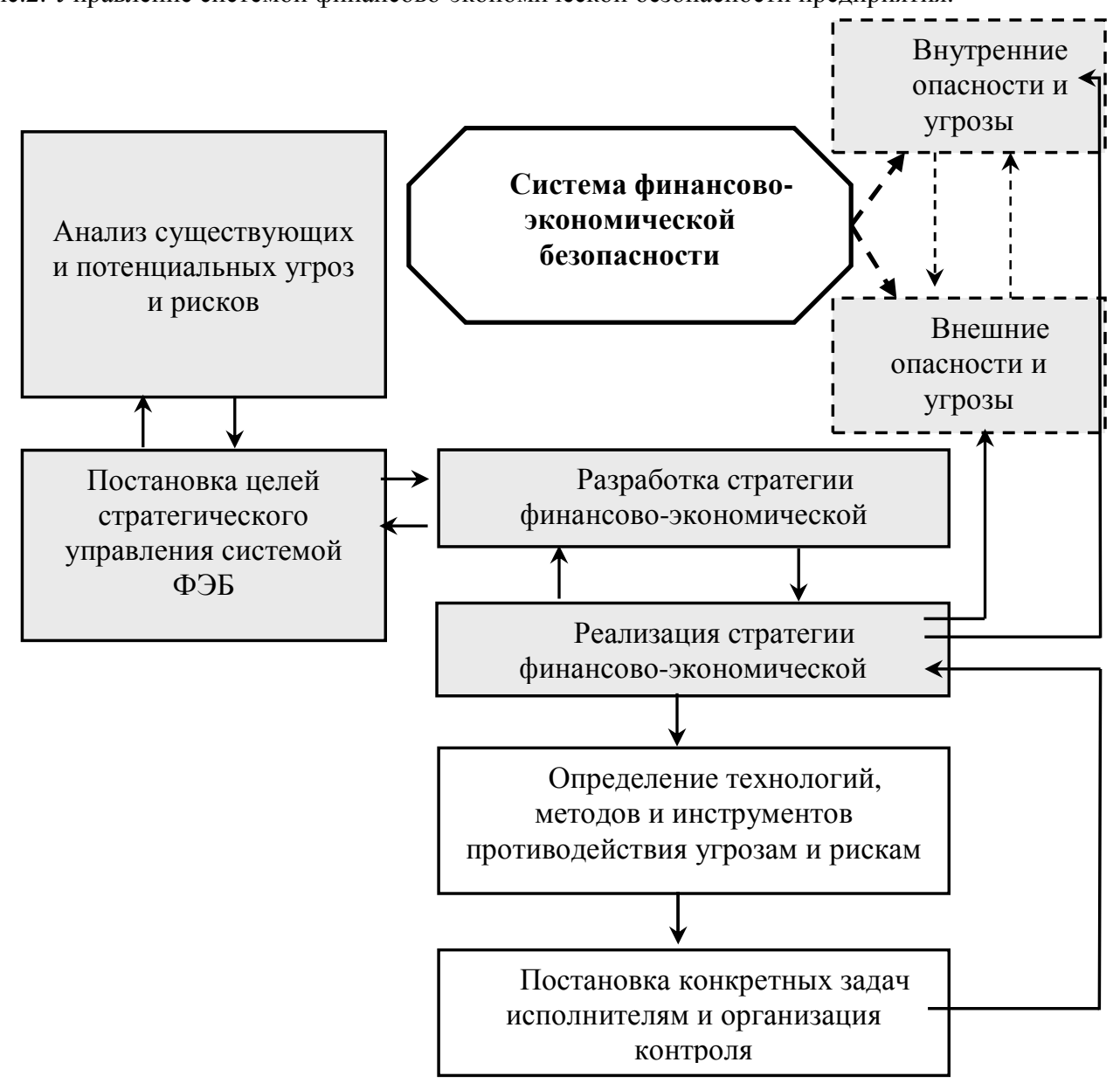

\section{7. ВЫВОДЫ}

Отмеченные особенности развития железнодорожного транспорта в Украине подтверждают, что в последние годы основные проблемы, которые присущи железным дорогам в развитых европейских странах, присущи и для украинского железнодорожного транспорта. В Украине они имеют особенно острый характер. Во-первых, кризисные явления в национальной экономике углублялись в течение нескольких десятилетий. Во-вторых, наблюдается неопределенность в формах и сроках реформирования железнодорожного транспорта Украины. А это провоцирует неопределенность и риски в экономической деятельности этого вида транспорта. Реформы, которые начались на ЖДТ, кроме централизации финансовых потоков и систем управления, повышения тарифов и создания нового аппарата управления холдингами, пока еще не дают перспектив субъектам хозяйствования. Поэтому весьма актуальной является разработка целостной концепции и 
последовательной реализации финансово-экономической безопасности предприятий ЖДТ УЗ.

\section{ЛИТЕРАТУРА}

[1] Васильців Т.Г., Економічна безпека підприємництва Украӥни: стратегія та механізми зміџнення, Монографія, Львів: Арал, 2008..

[2] Головкова Л.С., Сукупний економічний потенціал корпорації: формування тарозвиток, монографія, Запоріжжя: КПУ, 2009.

[3] Державна цільова програма реформування залізничного транспорту на 2010-2019 роки [Електронний ресурс].

[4] За вагон - хоть в огонь, [Электронный ресурс], Режим доступа: http://zadonbass.org/news/all/message_61499.

[5] Дикань В.Л., Дикань I.В., Воловельська, Економічна безпека підприємства: навчальний, посібник, Х.: УкрДАЗТ, 2011.

[6] Дикань В.Л., В.В. Компанієць, І.Л. Назаренко, Техніко-економічний аналіз діяльності підприємств залізничного транспорту, підручник, Х.: УкрДАЗТ, 2013.

[7] Дикань В.Л., Украӥнська модель економічної системи як нова концепція розвитку національної економіки, Вісник економіки транспорту і промисловості. Збір наук. Праць, Х.: УкрДАЗТ, 2013., 44, С. 11 - 17.

[8] Дикань В.Л., Розвиток промислового потенціалу украӥнських підприємств, Вісник економіки транспорту і промисловості. Збір наук. Праць, Х.: УкрДАЗТ, 2014, № 46, С. 136 - 142.

[9] Момот А. В., Методичні підходи до визначення ефективності курсування швидкісних та високошвидкісних поїдів, Наука та прогрес транспорту. Вісник Дніпропетровського національного університету залізничного транспорту імені академіка В. Лазаряна, 2013, № 6, С. 4562.

[10] Сичов В.О., Вектори реформування залізничної галузі Украӥни, Локомотив-информ, 2013, № 5, С. 25-31.

[11] Стратегічні напрями розвитку транспортної галузі Украӥни у післякризовий періо, К. : НІСД, 2011.

[12] Ткач А.А. Інституцііональна економіка. Нова інституціональна економічна теорія, К. : Центр учбової літератури, 2007.

[13] Ткач А., Специфікація прав власності як базисного економічного інституту ринкової інфраструктури, Наукові праці Донецького національного технічного університету. Серія: економічна. Випуск 75. - Донецьк: ДонНТУ, 2004 - С.229-236.

[14] Транспортна стратегія Украӥни на період до 2020 року, [Електронний pecypc],

Режим Доступу: http://www.mintrans.gov.ua/uk/discussion/15621.html.

[15] http://www.segodnya.ua/economics/transport/skorostnye-zhd-perevozki-viyune-stali-rekordnymi-dlya-ukrainy-629677.html.

[16] http://zakon2.rada.gov.ua/laws/show/1390-2009 
[17] Комплексна методика визначення рівня економічної безпеки, оцінки ризиків та ймовірності банкрутства підпиємств, монографія, ВЛ, Дикань, ІЛ Назаренкр, Харків: УкрДАЗТ, 2010

\section{DEVELOPMENT APPROACHES TO FINANCIAL AND ECONOMIC SECURITY CONCEPTION OF ENTERPRISES UNDER RAILWAY SECTOR REFORM}

The conditions of Ukrainian railway transportation and its reforming objects in terms of PJSC "Ukrainian Railway" are discussed in the article. The objective of the article are the theoretical approaches and practical recommendations in the concept development of financial and economic security that enables Ukrainian railway transportation reforms.

It is substantiated that an increasing competition, the variety of economic and entrepreneurial internal and external risks, uncertainty of business environment are characteristics of modern Ukrainian economy. The problem of financial and economic security of each enterprise is singularized from the common system of country economic security. The terms and variations of rail transport facilities going private and going public were taken into detailed consideration in the undertaken study.

It is set forth forcefully that Ukrainian railway transportation system reforming is an objective necessity today. It is the first step in the process of Ukrainian railway transportation adaptation to the European Union standards. Besides, the transparent mechanisms for provision of ability for private companies to enter the market of railway transportation are created. The author presented a threat model of Ukrainian railway transportation economic security.

The author`s development approach to financial and economic security conception of enterprise is presented. It is presented in the form of the strategic management system by financial and economic security of enterprise. The consideration of existing and potential threats and risks determines the operational and predictive purposes of economic security system. It helps to make relevant mechanisms and instruments for its achievement.

It has been argued that in consequence of Ukrainian railway transportation reforming the configuration of intraregional communications can be changed, and thus political, economic and cultural potential in a variety of regions will increase.

Keywords: financial and economic security, railway transportation, reforming of Ukrainian Railway, concept, going private, economic security threats, uncertainty.

\section{BEZPIECZEŃSTWO FINANSOWE I EKONOMICZNE PRZEDSIĘBIORSTW SEKTORA KOLEJOWEGO}

W artykule zostały omówione warunki funkcjonowania ukraińskiego transportu kolejowego i jego reformy na przykładzie PJSC "Ukraińska Kolej". Celem artykułu jest przedstawienie teoretycznych i praktycznych zaleceń co do podejścia w rozwoju koncepcji zabezpieczenia finansowego i gospodarczego, który umożliwia reformy ukraińskiego transportu kolejowego.

Udowodniono, że rosnąca konkurencja, różnorodność zagrożeń wewnętrznych i zewnętrznych, gospodarczych i przedsiębiorczych, niepewność otoczenia biznesu to cechy nowoczesnej gospodarki ukraińskiej. Problem finansowego i gospodarczego bezpieczeństwa każdego przedsiębiorstwa nie jest odosobniony i ściśle związany jest ze wspólnym systemem bezpieczeństwa ekonomicznego kraju. W artykule omówione warunki oraz typy przemian gospodarczych transportu kolejowego. Reformowanie ukraińskiego systemu transportu kolejowego jest dziś koniecznością. Jest to pierwszy krok w procesie adaptacji ukraińskiego transportu kolejowego do standardów Unii Europejskiej. Poza tym, tworzone są przejrzyste mechanizmy zapewniania firmom prywatnym wejście na rynek transportu 
kolejowego. W artykule autor przedstawił model zagrożenia ukraińskiego transportu kolejowego dla bezpieczeństwa ekonomicznego. Uwzględniając istniejące i potencjalne zagrożenia określono cele operacyjne i predykcyjnych systemów bezpieczeństwa ekonomicznego. Jest to pomocne przy doborze odpowiednich mechanizmów i instrumentów do jego realizacji.

Stwierdzono, że w związku z reformami ukraińskiego transportu kolejowego, różnym konfiguracjom został poddany również transport wewnątrzregionalny, przez co potencjał polityczny, ekonomiczny i kulturalny w różnych regionach wzrośnie.

Słowa kluczowe: finansowo-gospodarcze bezpieczeństwo, transport kolejowy, reforma ukraińskiej kolei, prywatyzacja, występowanie zagrożeń bezpieczeństwa ekonomicznego.

DOI:10.7862/rz.2015.hss.39

Przesłano do redakcji: wrzesień 2015

Przyjęto do druku: październik 2015 